\title{
Generation of induced pluripotent stem cells from human cord blood cells with only two factors: 0 ct4 and Sox2
}

\author{
Alessandra Giorgetti ${ }^{1,5}$, Nuria Montserrat ${ }^{1,5}$, Ignacio Rodriguez-Piza ${ }^{1}$, Carmen Azqueta $^{2}$, Anna Veiga $^{1} \&$ \\ Juan Carlos Izpisúa Belmonte ${ }^{1,3,4}$
}

\begin{abstract}
${ }^{1}$ Center for Regenerative Medicine in Barcelona, Dr. Aiguader, Barcelona, Spain. ${ }^{2}$ Banc de Sang i Teixits, Vall d'Hebron, Paseo Vall d'Hebron, Barcelona, Spain. ${ }^{3}$ Gene Expression Laboratory, The Salk Institute for Biological Studies, La Jolla, California, USA. ${ }^{4}$ Networking Center of Biomedical Research in Bioengineering, Biomaterials and Nanomedicine (CIBER-BBN), Barcelona, Spain. ${ }^{5}$ These authors contributed equally to this work. Correspondence should be addressed to J.C.I.B.
\end{abstract} (belmonte@salk.edu or izpisua@cmrb.eu).

Published online 1 April 2010; doi:10.1038/nprot.2010.16

\begin{abstract}
Induced pluripotent stem cells (iPSC) provide an invaluable resource for regenerative medicine as they allow the generation of patient-specific progenitors with potential value for cell therapy. However, in many instances, an off-the-shelf approach is desirable, such as for cell therapy of acute conditions or when the patient's somatic cells are altered as a consequence of a chronic disease or aging. Cord blood (CB) stem cells appear ideally suited for this purpose as they are young cells expected to carry minimal somatic mutations and possess the immunological immaturity of newborn cells; additionally, several hundred thousand immunotyped CB units are readily available through a worldwide network of CB banks. Here we present a detailed protocol for the derivation of CB stem cells and how they can be reprogrammed to pluripotency by retroviral transduction with only two factors (0CT4 and SOX2) in 2 weeks and without the need for additional chemical compounds.
\end{abstract}

\section{INTRODUCTION}

Human induced pluripotent stem cells (iPSC) derived from adult somatic cells could be used in regenerative medicine to repair tissues damaged by disease or injury. Although human iPSC have been generated from various type of somatic cells, such as skin fibroblasts ${ }^{1}$, keratinocytes ${ }^{2}$, neural stem cells (NSCs) ${ }^{3}$, blood cells $s^{4,5}$ and cord blood-derived endothelial cells $(\mathrm{CBEC})^{6}$, scientists are still debating the best sources from which to derive iPSC. Further studies have shown that the age, origin and cell type used has a profound impact on the reprogramming efficiency as well as the quality of iPSC generation $^{2,7}$. A desirable protocol should aim to not only optimize all these parameters, but also to reduce both the number of factors used and the time required for reprogramming. A key observation in this regard is the recent study by Kim et al. ${ }^{3}$ where iPSC were generated from adult NSCs by direct reprogramming with either two transcription factors (OCT4 and KLF4) or one transcription factor (OCT4) ${ }^{8}$. However, NSCs are usually rare and difficult to access, representing a complicated target for reprogramming. Recently, the possibility of reprogramming blood cells to pluripotency has suggested an alternative source of somatic cells to generate iPSC. In particular, iPSC have been generated from mobilized peripheral blood $(\mathrm{mPB})^{4}$ or bone marrow $(\mathrm{BM})^{5} \mathrm{CD} 34+$ derived cells by ectopic expression of OCT4, SOX2, KLF4 and c-MYC. Although these cells are certainly an accessible and widely used source, they may have accumulated genomic alterations as a result of aging or disease, and the isolation of hematopoietic stem cells could represent a health risk for the donor'.

Cord blood (CB) stem cells, currently widely used as a source of hematopoietic stem cells for transplantation, could overcome these problems. The main practical advantages of using $\mathrm{CB}$ stem cells are the relative ease of procurement, the absence of risks for the donors and the ability to store fully tested and HLA-typed samples in public banks ${ }^{10}$, available for immediate use. Another relevant consideration is that $\mathrm{CB}$ cells are young and are expected to carry minimal somatic mutations ${ }^{11}$.
We have demonstrated that CB CD133 + cells can be reprogrammed to pluripotency faster than fibroblasts and keratinocytes by ectopic expression of only two transcription factors (OCT4 and SOX2 $)^{12}$. CB CD133 + cells express a subset of pluripotency-associated genes (OCT4, SOX2, NANOG and CRIPTO), albeit at much lower levels than human ES cells (hESCs) (data not shown). On the other hand, the endogenous levels of c-MYC and KLF4 are higher in CB CD133 + cells compared with fibroblasts and keratinocytes (Fig. 1). The combination of low levels of pluripotency markers with the high levels of KLF4 and c-MYC may allow for enhanced reprogramming of CB CD133 + cells. Cord blood iPS (CBiPS) cells are generated with only two factors offer new possibilities for investigating the molecular mechanisms that underline reprogramming to pluripotency.

Furthermore, and from a more practical point of view, CB cells could represent, in the future, an alternative, safer source of iPSC amenable to worldwide banking and distribution.

Here, we present a detailed protocol for the derivation of $\mathrm{CB}$ CD133 + cells and how to reprogram them to pluripotency by retroviral transfection of OCT4 and SOX 2 in 2 weeks without the need for additional chemical compounds.

\section{Experimental design}

Derivation of CB CD133 + cells. Our protocol first focuses on the importance of selecting the correct cell subpopulation, within CB, for reprogramming. CD133 antigen is known as a stem cell marker for hematopoietic stem and progenitor cells. In contrast to CD34, the most widely used marker for hematopoietic stem cells (HSC) enrichment, CD133 is not found in late progenitors, providing a selection of a more homogeneous population enriched in HSC. CD133 + cells, which represent a small fraction of total nucleated cells in human CB (0.1-0.5\%), are positively selected using the standard immunomagnetic separation system. 
Retrovirus production. We produce retroviral vectors using the Phoenix Amphotropic packaging cell line. Retroviral vectors based on the Moloney murine leukemia virus (MuLV) have been extensively used as the primary tool for gene delivery into hematopoietic cells; however, they have also shown low transduction efficiencies. We could improve the gene transfer of MuLV-based vectors into $\mathrm{CD} 133+$ cells using a retronectin-facilitated protocol.

Transduction of CD133 + cells. The standard protocol used for fibroblast reprogramming needs to be modified for the transduction of CD133 + cells, which are in a quiescent state and grow in suspension. First, because the integration and expression of retroviral constructs requires mitotic division of the target cells, it is important to culture the $\mathrm{CD} 133$ + cells in vitro in the presence of SCF, Flt3-ligand, TPO and IL-6 cytokines for $24 \mathrm{~h}$. Second, to increase the transduction efficiency, $\mathrm{CD} 133+$ cells are seeded over retronectin-coated plates pre-absorbed with the viral particles. CD133 + cells are infected three times every $12 \mathrm{~h}$; on day 3 post-infection, cells are transferred to 6-well plates containing irradiated human fibroblasts (HFF) and hES medium and cultured until iPS colonies appear.

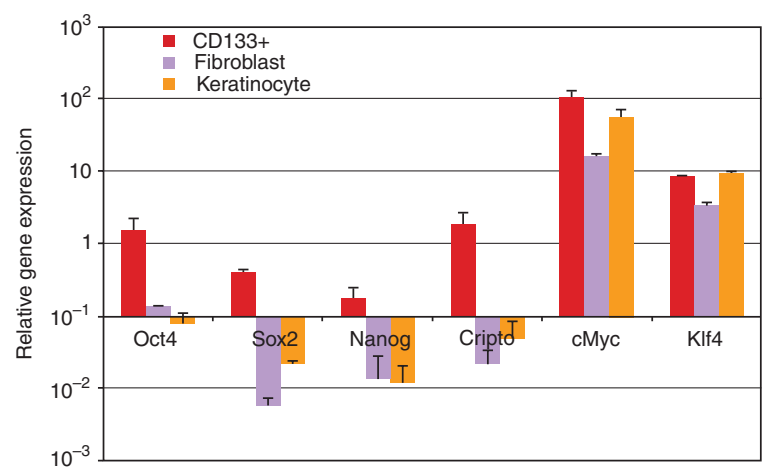

Figure 1 | Quantitative RT-PCR analysis for pluripotent markers and the two transcription factors C-MYC and KLF4. Comparison of endogenous levels of OCT4, SOX2, NANOG, CRIPTO, C-MYC and KLF4 among cord blood (CB) CD133+ cells, fibroblast and keratinocytes. Transcript levels were normalized to GAPDH levels. Error bars indicate the s.d. generated from triplicates.

CBiPS cells. As early as $9 \mathrm{~d}$ post-transduction with OCT4 and SOX2 (OS), small colonies start to appear, and after $15 \mathrm{~d}$, some of the colonies exhibit a typical hESC morphology.

\section{MATERIALS}

\section{REAGENTS}

- Umbilical CB unit providing umbilical CB $\mathbf{\Delta}$ CRITICAL Informed consent must be obtained from the parents. Extraction must conform to national and institutional regulations.

- Retroviral vectors expressing the reprogramming transgene (see REAGENT SETUP)

- Phoenix amphotropic 293 cells (ATCC, cat. no. SD 3443)

- Mitotically inactivated human foreskin fibroblasts (ATCC, cat. no. CRL-2429)

- Phosphate-buffered saline (PBS) without calcium and magnesium (Invitrogen, cat. no. 2531)

- EDTA disodium 0.5 M (Sigma-Aldrich, cat. no. E7889)

- Lympholyte-H (Cederlane, CL5016) ! CAUTION Toxic by skin contact; wear gloves and lab coat when handling.

- CD133 microbead kit (Miltenyi Biotec, cat. no. 130-050-801)

- DMEM (Invitrogen, cat. no. 11965-092)

- OPTIMEM (Invitrogen, cat. no. 31985-062)

- Knockout (KO)-DMEM (Invitrogen, cat. no. 10829-018)

- Heat-inactivated FBS (Invitrogen, cat. no. 10270-106)

- KO serum replacement (KOSR; Invitrogen, cat. no. 10828-028)

- $20 \%$ human serum albumin solution (HSA) (Instituto Grifols, SA, cat. no. 670612)

- GlutaMAX (Invitrogen, cat. no. 35050-038)

- Penicillin-streptomycin (Invitrogen, cat. no. 15140-122)

- Nonessential amino acid solution (Invitrogen, cat. no. 11140-050)

- 50 mM 2-mercaptoethanol (Invitrogen, cat. no. 31350-010) ! CAUTION

Toxic by inhalation and skin contact.

- Recombinant human stem cell factor (SCF, PeproTech, cat. no. 300-07)

$\Delta$ CRITICAL Dilute and store all the growth factors in appropriate aliquots according to the manufacturer's recommendations at $-20^{\circ} \mathrm{C}$ (see REAGENT SETUP).

- Recombinant human Flt3-ligand (Flt3, PeproTech, cat. no. 300-19) (see REAGENT SETUP)

- Recombinant human interleukin-6 (IL-6, PeproTech, cat. no. 200-06) (see REAGENT SETUP)

- Recombinant human thrombopoietin (TPO, PeproTech, cat. no. 300-18) (see REAGENT SETUP)

- Recombinant human fibroblast growth factor, basic (bFGF, PeproTech, cat. no. 100-18B) (see REAGENT SETUP)

- Retronectin (Takara, cat. no. T100A)

- $0.05 \%$ Trypsin-EDTA (Invitrogen, cat. no. 25300-054)

- Gelatin $0.1 \%$ solution (Millipore, cat. no. ES-006-B)
- DMSO (Sigma, cat. no. D4540) ! CAUTION Toxic by inhalation and skin contact.

- Trypan Blue stain (Invitrogen, cat. no. 15250-061)

- FuGENE 6 transfection reagent (Roche Applied Science, cat. no. 1181509001)

- Polybrene (10 $\mathrm{mg} \mathrm{ml}^{-1}$ ) (Chemicon, cat. no. TR-1003-6)

- hES medium (see REAGENT SETUP)

- Freezing medium (see REAGENT SETUP)

- Mouse IgG1 anti-human CD133-PE (Miltenyi Biotec, cat. no. 130-080-801)

- Mouse IgG1, k anti-human CD45-APC (Becton Dickinson, cat. no. 555485)

EQUIPMENT

- Class-II cabinet with aspirator for tissue culture (Bio-II-A, Telstar)

- Class-II cabinet with aspirator for tissue culture and space for stereomicroscope (Bio-II-A/G, Telstar)

- Aspirator tube assembly (Sigma, cat. no. A5177)

- Stereomicroscope (SZX12, Olympus)

- Low-end color video camera (TKC1481BEG, JVC)

- Low-end 8-inch LCD display (TV304, BOMAN)

- Inverted tissue culture microscope with phase contrast and epifluorescence, with $\times 5, \times 10, \times 20$ and $\times 40$ objectives (Leica DMIL, Leica)

- Thermostatized tissue culture centrifuge and swinging rotor with adapters for 15- and 50-ml tubes and microplates (Allegra X-12R centrifuge with SX4750A rotor, Beckman Coulter)

- Cell-culture incubator set at $37^{\circ} \mathrm{C}, 5 \% \mathrm{CO}_{2}$ (REVCO, cat. no. RCO3000D-9-VBC)

- Microcentrifuge (Eppendorf, cat. no. 5424)

- Tissue culture dish, $100 \mathrm{~mm}$

- Tissue culture plates, 24 well and 6 well

- Mini-Macs separator (Miltenyi Biotec, cat. no. 130-090-312)

- MS column (Miltenyi Biotec, cat. No. 130-041-301)

- Pre-separation filters (Miltenyi Biotec, cat.no. 130-041-407)

- Syringe, $2.5 \mathrm{ml}$ (PentaFerte, cat. no. 08L01)

- Stripper micropipette (Mid Atlantic, cat. no. MXL3-STR)

- Stripper tips, $150 \mu \mathrm{m}$

- Conical tubes, 15 and $50 \mathrm{ml}$

- Cryovials (Sigma, cat. no. V7634-500EA)

- Cryo $1{ }^{\circ} \mathrm{C}$ freezing container, 'Mr. Frosty' (Nalgene, cat. no. 5100-0001)

- Slide flask (Nunc, cat. no. 170920)

- Bottle-top filter system, $0.22 \mu \mathrm{m}, 500 \mathrm{ml}$ (Millipore, cat. no. SCGPU05RE)

- Storage bottle, $500 \mathrm{ml}$ (Corning, cat. no.430282)

- Filter, Millec-HV PVDF, $0.45 \mu \mathrm{m}$ (Millipore, cat. no. SLHV033RS)

- Cell counter or hemocytometer

- Moflo Cell Sorter (Dako Cytomation) 


\section{REAGENT SETUP}

PBS-EDTA buffer Add $2 \mathrm{mM}$ EDTA to $500 \mathrm{ml} \mathrm{PBS} \mathrm{(vol/vol)} \mathrm{and} \mathrm{cool} \mathrm{the}$ solution at $4{ }^{\circ} \mathrm{C}$ before use. Store at $4{ }^{\circ} \mathrm{C}$ and use within 2 weeks. iPS cell-freezing medium Mix 10\% DMSO (vol/vol) and 90\% FBS (vol/vol). Use immediately.

Complete DMEM media for 293 Phoenix Amphotropic cells or human fibroblasts High glucose DMEM, 10\% FBS, GlutaMAX $200 \mathrm{mM}$, penicillin-streptomycin $\left(100 \mathrm{U} \mathrm{ml}^{-1}, 100 \mu \mathrm{g} \mathrm{ml}^{-1}\right)$. To prepare $500 \mathrm{ml}$ of medium, remove $60 \mathrm{ml}$ of DMEM from a new bottle and add $50 \mathrm{ml} \mathrm{FBS}$, $5 \mathrm{ml}$ GlutaMax and $5 \mathrm{ml}$ penicillin-streptomycin. Store at $4{ }^{\circ} \mathrm{C}$ in the dark and use within 2-3 weeks.

bFGF Spin the lyophilized bFGF vial briefly to bring the contents down. Prepare HSA $0.2 \%$ in PBS in a sterile tube (1:50 dilution): $9.8 \mathrm{ml}$ PBS + $0.2 \mathrm{ml}$ HSA. Dissolve bFGF with PBS at $0.2 \%$ HSA to obtain a final concentration of $100 \mu \mathrm{g} \mathrm{ml}^{-1}$. Make $50 \mu \mathrm{l}$ aliquots in screw-cap microcentrifuge tubes and store at $-20^{\circ} \mathrm{C}$.
SCF, IL-6, TPO and Flt-3 ligand Centrifuge the lyophilized SCF, IL-6, TPO and Flt-3 ligand vials for $1 \mathrm{~min}$ so that all the content will fall down to the bottom. Prepare HSA $0.2 \%$ in PBS in a sterile tube (1:50 dilution). Dissolve SCF, IL-6, TPO and Flt-3 ligand with PBS $0.2 \%$ HSA to obtain a final concentration of $5 \mathrm{ng} \mathrm{ml}{ }^{-1}$. Prepare $50 \mu \mathrm{l}$ aliquots in screw-cap microcentrifuge tubes. Store at $-20^{\circ} \mathrm{C}$. hES cell medium To prepare $500 \mathrm{ml}$ of hES medium, mix $387.5 \mathrm{ml}$ of KO-DMEM with $100 \mathrm{ml}$ of KOSR, $5 \mathrm{ml}$ of Glutamax ( $1 \mathrm{mM}$ ), $5 \mathrm{ml}$ of penicillin-streptomycin, $5 \mathrm{ml}$ of nonessential amino acids $(100 \mu \mathrm{M}), 500 \mu \mathrm{l}$ of 2-mercaptoethanol $(100 \mu \mathrm{M})$ and $50 \mu \mathrm{lof} \mathrm{bFGF}\left(10 \mathrm{ng} \mathrm{ml}^{-1}\right)$. Filter the medium with a bottle-top $0.22-\mu \mathrm{m}$ filter and store at $4{ }^{\circ} \mathrm{C}$ (maximum 1 week). Gelatin-coated culture dishes Add $0.1 \%$ gelatin solution to cover the bottom of the dish. Incubate the dish for at least $30 \mathrm{~min}$ at $37^{\circ} \mathrm{C}$. Aspirate and leave to dry for at least $10 \mathrm{~min}$ in the tissue culture hood. Use immediately. Retroviral vectors pMSCV-based retroviral vectors expressing FLAG-tagged OCT4, SOX2, KLF4 and c-MYC are available from Addgene (e.g. 20072, 20073, 20074 and 20075, respectively).

\section{PROCEDURE}

\section{Umbilical CB collection TIMING 5 min}

1) Collect umbilical CB into an integral plastic blood collection bag by venipucture (Fig. 2a).

$\triangle$ CRITICAL STEP Patients' informed consents must be obtained before the delivery.

$\triangle$ CRITICAL STEP The CB should be stored at $4{ }^{\circ} \mathrm{C}$ during the transport and before separation. Processing of the CB should be carried out as quickly as possible to prevent the blood hemolysis or coagulum formation. Do not use samples older than $15 \mathrm{~h}$.

\section{Isolation of umbilical CB mononuclear cells using Lympholyte-H density gradient $\bigcirc$ TIMING $\sim 2 \mathrm{~h}$}

2| All subsequent steps should be carried out in a tissue culture hood. Dilute the CB 1:3 with sterile PBS-EDTA in a sterile 500-ml bottle.

3| Layer $35 \mathrm{ml}$ of diluted blood slowly on $15 \mathrm{ml}$ of Lympholyte-H layer (ratio 3:1) in a 50-ml tube (Fig. 2b).

$\triangle$ CRITICAL STEP Do not mix the tube; make sure the layers are not disturbed.

4 Centrifuge for $25 \mathrm{~min}$ at $400 \mathrm{~g}$ at room temperature $\left(20-22^{\circ} \mathrm{C}\right)$.

$\triangle$ CRITICAL STEP Acceleration and deceleration should be kept at speeds as low as possible to avoid any disturbance to cells in the white layer (Fig. 2c).

5| Collect the interphase cells (white layer) in a $50-\mathrm{ml}$ tube using a plastic pipette.

$\triangle$ CRITICAL STEP Some cells might attach to the side of the tube in the form of a pellet; 'rub' them gently using the end of the pipette and collect them.

6| Dilute the cell suspension with PBS-EDTA (ratio 1:1) and centrifuge for $5 \mathrm{~min}$ at $300 \mathrm{~g}$ at room temperature.

7| Pipette off the supernatant and pull together the pellets, resuspending the pellets in $50 \mathrm{~mL}$ of PBS-EDTA.

8| Count the total number of mononuclear cells using a hematocytometer and asses the viability using Trypan Blue exclusion method (as described in Box 1).

Figure 2 | Umbilical cord blood collection and separation. (a) An average of $75 \mathrm{ml}$ of umbilical cord blood is collected into a plastic blood bag by venipucture. (b) Before centrifugation, two distinct layers can be clearly distinguished: the diluted blood (B) over the Lympholyte-H (F). (c) After centrifugation, there should be a well-defined white layer (W) at the interface, red blood cells on the bottom below the Lympholyte (R) and plasma with platelets on the top $(P)$.
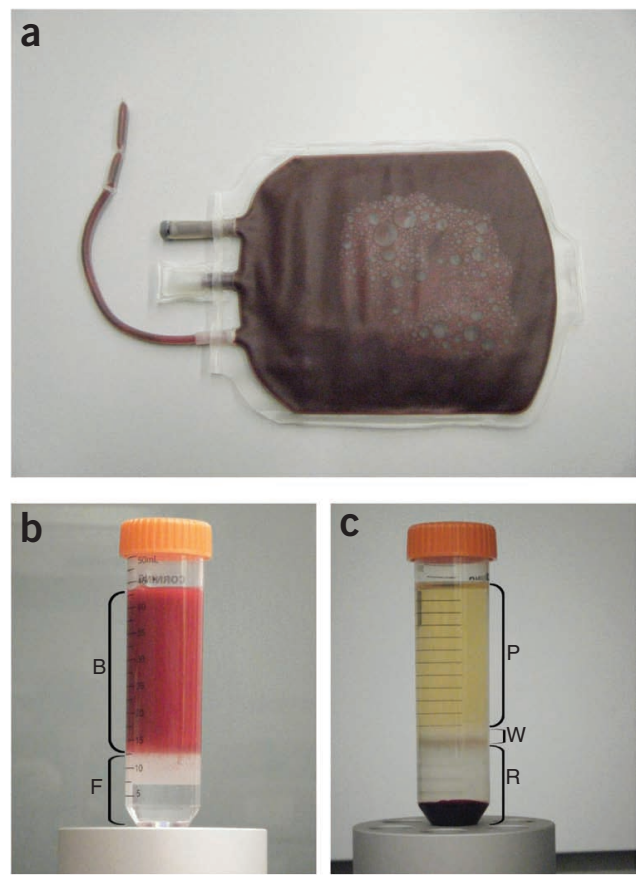


\section{BOX 1 | CELL COUNTING}

The following steps are used to count the total number of mononuclear cells in $10 \mu \mathrm{l}$ of cell suspension:

1. Place $10 \mu \mathrm{l}$ of mononuclear cell suspension in an appropriate tube containing $90 \mu \mathrm{l}$ of Trypan Blue and mix gently.

2. Place $10 \mu \mathrm{l}$ of stained cells in a hemocytometer and count the number of alive (unstained) and dead (stained blue) cells.

3. Calculate the average number of unstained cells in at least three quadrants and multiply by $10^{4}$ to find the number of cells per ml.

The percentage of viable cells is the number of viable cells divided by the number of total cells.

The following steps are used to count the CD133 + selected cells or Phoenix Amphotropic 293 cells in $10 \mu$ l of cell suspension:

1. Place $10 \mu \mathrm{l}$ of cell suspension in an appropriate tube and add $10 \mu \mathrm{l}$ of Trypan Blue and mix gently.

2. Place $10 \mu \mathrm{l}$ of stained cells in a hemocytometer and count the number of alive (unstained) and dead (stained blue) cells.

3. Calculate the average number of unstained cells in at least three quadrants and multiply by $10^{3}$ to find the number of cells per ml.

9| Centrifuge the sample for $5 \mathrm{~min}$ at $200 \mathrm{~g}$ at room temperature to eliminate platelets.

$\triangle$ CRITICAL STEP Activation of platelets may disturb further isolation.

? TROUBLESHOOTING

10| Pipette off the supernatant and resuspend cell pellet in a final volume of $300 \mu \mathrm{l}$ of PBS-EDTA per $10^{8}$ total cells.

$\Delta$ CRITICAL STEP For less than $10^{8}$ total cells, use $300 \mu \mathrm{l}$ of PBS-EDTA.

\section{Isolation of CD133 + cells $\bigcirc$ TIMING $\sim 1 \mathrm{~h}$}

11| Add $100 \mu \mathrm{L}$ FcR blocking reagent to $10^{8}$ total cells resuspended in $300 \mu \mathrm{l}$ of PBS-EDTA.

12| Add $100 \mu \mathrm{L}$ CD133 microbeads to $10^{8}$ total cells.

$\Delta$ CRITICAL STEP Work fast and keep the cells cold using cold solutions to avoid non-specific cell labeling.

$\Delta$ CRITICAL STEP When working with smaller cell numbers, use $100 \mu \mathrm{l}$ of CD133 microbeads and FCR blocking. When working with larger cell numbers, scale up all reagent volumes (e.g., for $2 \times 10^{8}$ total cells use twice the volume of all indicated reagents).

13| Mix well and incubate cells for 30 min at $4-8^{\circ} \mathrm{C}$.

$\Delta$ CRITICAL STEP During incubation, gently shake the tube every few minutes to avoid clumping and cellular adherence.

14| Wash cells by adding up to $50 \mathrm{ml}$ of PBS-EDTA.

15| Centrifuge for $5 \mathrm{~min}$ at $300 \mathrm{~g}$ at room temperature.

16| Pipette off the supernatant.

17| Resuspend cell pellet in $500 \mu \mathrm{l}$ of PBS-EDTA per $10^{8}$ total cells and proceed to magnetic separation.

18| Use one MS column up to $10^{7}$ magnetically labeled cells or up to $2 \times 10^{8}$ total cells.

$\Delta$ CRITICAL STEP When working with larger cell numbers, divide the cell suspensions using two MS columns.

19| Place the column in the magnetic field of the MACS Separator and place a 15-ml tube under the column. Rinse the column with $500 \mu \mathrm{l}$ of PBS-EDTA.

20| Apply $500 \mu \mathrm{l}$ cell suspension onto the column and allow the negative cells to pass through.

$\Delta$ CRITICAL STEP Avoid forming bubbles/foam that can disturb migration of cells through the column.

21| Wash the column twice with $500 \mu \mathrm{l}$ PBS-EDTA.

22| Remove the column from separator and place the column on a new collection 15-ml tube.

23| Pipette $1 \mathrm{ml}$ of PBS-EDTA onto the column and firmly flash out the cell fraction magnetically labeled using the plunger.

24| Repeat magnetic separation Steps 19-23. Apply the eluted cells to a new pre-filled column. 


\section{BOX 2 | FLOW CYTOMETRY ANALYSIS}

Flow cytometry analysis provides information about the purity of isolated CD133+ cells.

1. To prepare cells for flow analysis, add $10 \mu \mathrm{l}$ of CD133-PE and $20 \mu \mathrm{l}$ of CD45-APC in cell suspension (50,000 in $500 \mu \mathrm{l}$ of PBS), mix well and incubate for $15 \mathrm{~min}$ in the dark at room temperature.

2. Wash the cells with $2 \mathrm{~mL}$ of PBS with $2 \%$ human serum albumin (HSA) and centrifuge at $600 \mathrm{~g}$ for $5 \mathrm{~min}$ at room temperature.

3. Resuspend the cell pellet in $500 \mu \mathrm{l}$ of PBS with $2 \%$ HSA containing propidium iodide (final concentration $10 \mu \mathrm{g} \mathrm{ml}^{-1}$ ) to detect dead cells.

4. Analyses: all our analyses were carried out on Moflo Cell Sorter (DakoCytomation) applying Summit software.

25| Count the cells using hematocytometer and asses their viability using Trypan Blue exclusion method (as described in Box 1).

26| Take $5 \times 10^{4}$ cells and carry out the flow cytometry (FACS) analysis to evaluate the efficiency of the magnetic separation (as described in Box 2).

27| Plate the CD133 + cells $\left(50,000 \mathrm{ml}^{-1}\right)$ in complete DMEM supplemented with SCF $\left(50 \mathrm{ng} \mathrm{ml}^{-1}\right)$, Flt-3 ligand $\left(50 \mathrm{ng} \mathrm{ml}^{-1}\right)$, IL-6 (10 $\left.\mathrm{ng} \mathrm{ml}^{-1}\right)$ and TPO (10 $\left.\mathrm{ng} \mathrm{ml}^{-1}\right)$ in a 6-well plate. Incubate at $37{ }^{\circ} \mathrm{C}, 5 \% \mathrm{CO}_{2}$ for $24 \mathrm{~h}$.

$\triangle$ CRITICAL STEP As the integration and expression of retroviral constructs require mitotic division of the target cells, it is important to carry out a pre-stimulation step of $24 \mathrm{~h}$ to induce the quiescent CD133 + cells to enter in a proliferative status.

\section{Retrovirus production $\bigcirc$ TIMING $\sim 1$ week}

28| Defrost a vial of Phoenix Amphotropic 293 cells (for details see Box 3). If using other virus or production approaches, jump to Step 42.

! CAUTION Use Category 2 (or higher) tissue culture hoods and exercise due caution in the production, storage and use of recombinant retroviral particles.

29| Plate $\sim 2 \times 10^{6}$ cells in complete DMEM medium in 100-mm tissue culture dish and incubate at $37{ }^{\circ} \mathrm{C}, 5 \% \mathrm{CO}_{2}$ for $2 \mathrm{~d}$.

30| When the cells reach $80 \%$ confluence (1-2 d), aspirate medium, wash gently with PBS, aspirate and add $3 \mathrm{ml} 0.05 \%$ Trypsin-EDTA. Incubate for 1 min at $37^{\circ} \mathrm{C}$. Gently tap the tissue culture plate ensuring all cells are in suspension.

31 Add $10 \mathrm{ml}$ complete DMEM medium to the plate, collect cell suspension and transfer to a $50-\mathrm{ml}$ tube.

32| Centrifuge at $200 \mathrm{~g}$ for $5 \mathrm{~min}$ at room temperature.

33| Resuspend pellet in $10 \mathrm{ml}$ complete DMEM medium and count cells (as described in Box 1).

34 Plate $4 \times 10^{6}$ cells in $10 \mathrm{ml}$ final volume in 100 -mm culture dishes and place in a $37^{\circ} \mathrm{C}, 5 \% \mathrm{CO}_{2}$ incubator.

35| The next day, co-transfect Phoenix Amphotropic 293 cells with FuGENE-DNA complex according to the manufacturer's instructions. Briefly, place $0.873 \mathrm{ml}$ of OPTIMEM into separate $1.5-\mathrm{ml}$ tube (one for each of the plasmids to be transfected) and add $27 \mu \mathrm{l}$ of FuGENE 6 transfection reagent, gently tapping the tube to mix. Next incubate at

\section{BOX 3 | THAWING PHOENIX AMPHOTROPIC 293 CELLS}

To thaw Phoenix Amphotropic 293 cells, prepare and warm $10 \mathrm{ml}$ of complete DMEM in a $37^{\circ} \mathrm{C}$ water bath and proceed as follows:

1. Remove a vial of Phoenix Amphotropic 293 from liquid nitrogen tank and place immediately in a $37^{\circ} \mathrm{C}$ water bath.

2. When the cell suspension is almost fully thawed, remove the vial and spray with ethanol.

3. Open the vial and dropwise add $500 \mu \mathrm{l}$ of complete DMEM medium.

4. Using a $5 \mathrm{ml}$ pipette containing $3 \mathrm{ml}$ of complete DMEM medium, aspirate the cell suspension and transfer the cells into a 15-ml tube containing $7 \mathrm{ml}$ of complete DMEM medium.

5. Centrifuge at $200 \mathrm{~g}$ for $5 \mathrm{~min}$ at room temperature.

6. Pipette off the supernatant and resuspend the cell pellet in $8 \mathrm{~mL}$ of complete DMEM medium.

7. Plate the cell suspension in a 100 -mm tissue culture dish and place in a $37{ }^{\circ} \mathrm{C}, 5 \% \mathrm{CO}_{2}$ incubator. 
Figure 3 | Phoenix Amphotropic 293 cells post transfection.

(a) Representative image of Phoenix Amphotropic 293 cells $48 \mathrm{~h}$ after transfection (phase contrast image; scale bar, $100 \mu \mathrm{m}$ ). (b) The transfection efficiency of Phoenix Amphotropic 293 cells after $48 \mathrm{~h}$ should be close to $100 \%$. Scale bar, $100 \mu \mathrm{m}$. room temperature for 5 min. Add $9 \mu \mathrm{g}$ of pMSCV DNA plasmids dropwise into separate solutions of FuGENE-OPTIMEM and mix by tapping with a finger. Incubate at room temperature for $15 \mathrm{~min}$.

36 Add the FuGENE-DNA solution dropwise onto plate and return to a $37{ }^{\circ} \mathrm{C}, 5 \% \mathrm{CO}_{2}$ incubator overnight.

$\triangle$ CRITICAL STEP Gently add FuGENE-DNA complex solution dropwise. Phoenix Amphotropic 293 cells get detached easily from the plate if L-polylysine coating is not carried out.

37| Next day, change the media gently (10 $\mathrm{ml}$ per plate) and incubate overnight in a $32{ }^{\circ} \mathrm{C}, 5 \% \mathrm{CO}_{2}$ incubator. If desired check transfection efficiency (see Fig. 3 ).

$\triangle$ CRITICAL STEP Virus is more stable at $32{ }^{\circ} \mathrm{C}$, resulting in higher infectivity, although $37^{\circ} \mathrm{C}$ is acceptable.

$\Delta$ CRITICAL STEP At this time point, near 100\% confluence of cells should be transfected. Monitor transfection efficiency by using preferred GFP reporter plasmid (Fig. 3a,b).

38 Collect $5 \mathrm{ml}$ viral supernatant from every plate $48 \mathrm{~h}$ after transfection using plastic pipettes and filter the supernatant through a $0.45-\mu \mathrm{m}$ PVDF filter to remove any residual cells.

$\triangle$ CRITICAL STEP Use low protein-binding filters to avoid trapping the virus and reducing the titer.

PAUSE POINT Virus can be snap-frozen in cryovials using liquid nitrogen and stored at $-80^{\circ} \mathrm{C}$ or in liquid nitrogen for several months. We have observed some loss in infectivity upon freezing.

39| Add fresh $5 \mathrm{ml}$ of complete DMEM to every plate and place in a $37{ }^{\circ} \mathrm{C}, 5 \% \mathrm{CO}_{2}$ incubator.

$\triangle$ CRITICAL STEP Take care to avoid cells detaching from the tissue culture plates.

40| Add $1 \mu \mathrm{l}\left(10 \mathrm{mg} \mathrm{ml}^{-1}\right)$ of polybrene for each $\mathrm{ml}$ viral supernatant needed.

41 Every $12 \mathrm{~h}$ repeat Steps 38-40 to collect more viral supernatant. Collect twice more. Continue with Step 42 while carrying out these collections.

\section{Retroviral transduction of CD133 + cells $\bigcirc$ TIMING 2d}

42 Infection day 1: dispense an appropriate volume of retronectin solution $\left(15 \mu \mathrm{g} \mathrm{cm}^{-2}\right)$ into each well of a 24-well plate and incubate for $2 \mathrm{~h}$ at room temperature.

$\triangle$ CRITICAL STEP We recommend diluting the retronectin solution in PBS and dispensing $500 \mu$ of diluted retronectin into each well of a 24-well plate.

43| Remove retronectin solution and add $500 \mu$ of PBS containing $2 \%$ HSA (vol/vol) into each well for blocking.

44| Incubate the plate for $30 \mathrm{~min}$ at room temperature.

45| Remove the PBS-HSA solution and wash once with PBS.

46 Pre-load the viral supernatant derived from Phoenix Amphotropic 293 cells that have been filtered onto retronectincoated plates. Use equal amounts of each transcription factor to reach a total volume of $1 \mathrm{ml}(500 \mu \mathrm{l}$ for 0 OCT4 and $500 \mu \mathrm{l}$ for SOX2). 
47| Set the plate into a centrifuge pre-warmed to $32^{\circ} \mathrm{C}$ and centrifuge for $1 \mathrm{~h}$ at $2,000 \mathrm{~g}$ at $32{ }^{\circ} \mathrm{C}$.

$\triangle$ CRITICAL STEP If the titer of viral vector is high enough, then incubate for $4-6 \mathrm{~h}$ in a $32{ }^{\circ} \mathrm{C}, 5 \% \mathrm{CO}_{2}$ incubator. Centrifugation increases infectivity when the viral titer is low.

48| During centrifugation collect the CD133 + cells from Step 27 in a 15-ml tube and count the number of living cells (as describe Box 1).

49| Centrifuge for $5 \mathrm{~min}$ at $200 \mathrm{~g}$ at room temperature.

50| Suspend the pellet cells in complete DMEM medium supplemented with cytokines (SCF, Flt- 3, IL-6 and TP0) at a concentration of $8 \times 10^{4}$ cells per $\mathrm{ml}$.

51| Pipette off the viral supernatant from each well, taking care that the virus bound to the retronectin does not dry out, and wash each well with $1 \mathrm{ml}$ of PBS.

52| Pipette off PBS and immediately add $1 \mathrm{ml}$ of cell suspension into each well.

53| Incubate for $12 \mathrm{~h}$ in a $37^{\circ} \mathrm{C}, 5 \% \mathrm{CO}_{2}$ incubator.

54| Infection day 2: repeat Steps 38-40.

55| Remove $500 \mu \mathrm{l}$ from each well of the 24-well plates containing CD133 + cells and add $500 \mu \mathrm{l}$ of fresh viral supernatant to infect the cells a second time.

$\triangle$ CRITICAL STEP It is important to add the cytokine cocktail described in Step 27 (half the amount) to the fresh viral supernatant to keep the cells alive and proliferating (Fig. 4a).

56| Incubate for $12 \mathrm{~h}$ in a $37^{\circ} \mathrm{C}, 5 \% \mathrm{CO}_{2}$ incubator.

57| Repeat Steps 55 and 56 to infect the cells a third time and incubate for $24 \mathrm{~h}$ in a $37{ }^{\circ} \mathrm{C}, 5 \% \mathrm{CO}_{2}$ incubator.

$\triangle$ CRITICAL STEP We have noticed that infection efficiency, monitored by a constitutive GFP reporter retrovirus, can vary $(10-40 \%)$.

? TROUBLESHOOTING

Culturing transduced CD133 + cells $\bigcirc$ TIMING 2 weeks

58| Plate the HFF in a gelatin-treated 6-well plate.

59| Collect the cells in a $15-\mathrm{ml}$ tube $1 \mathrm{~d}$ after the last infection.

60| Centrifuge for 5 min at $200 \mathrm{~g}$ at room temperature.

61| Resuspend in $1 \mathrm{ml} \mathrm{hES} \mathrm{medium} \mathrm{and} \mathrm{plate} \mathrm{the} \mathrm{infected}$ CD133 + cells onto a 6-well plate containing HFF feeder and $1 \mathrm{ml}$ of hES medium.

62 After $2 \mathrm{~d}$ change the medium daily and maintain in culture until the iPS cell colonies emerge.

$\triangle$ CRITICAL STEP Because the first week of culture CD133+ cells are still growing in suspension, it is important to

Figure 4 | Morphology of cord blood (CB) CD133 + cells after infection. (a) $C B$ CD133 + cells growing attached on retronectin during the viral infection could change morphology, losing the round shape. (b) During the first week of reprogramming, CB CD133 + cells grow in suspension and only few of them start to attach to the feeder layer. Scale bar, $100 \mu \mathrm{m}$.
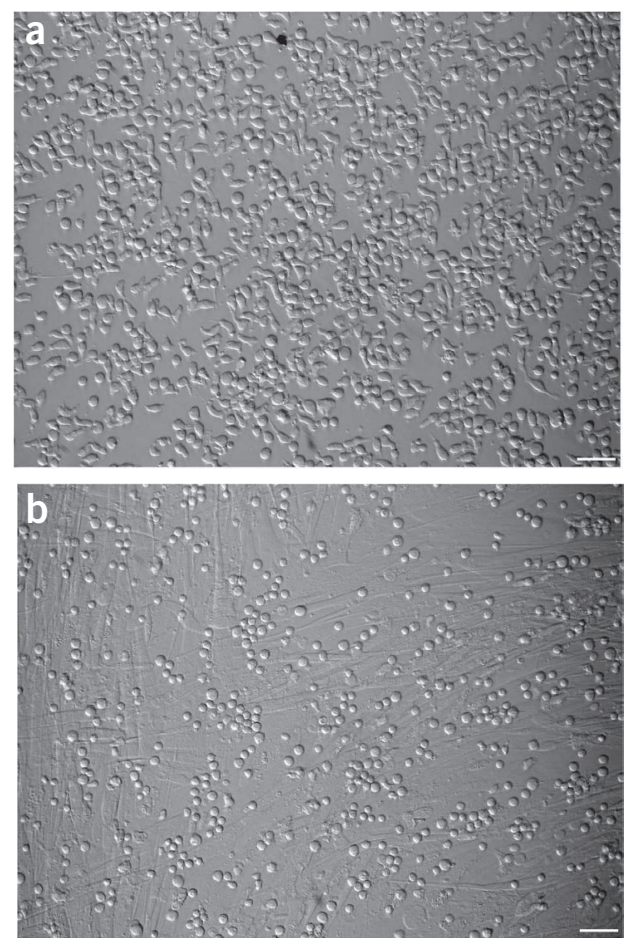
Figure 5 | Induced pluripotent stem cells (iPSC) from cord blood CD133+ cells. (a) Morphology of cord blood iPS (CBiPS) cell colonies obtained after the introduction of two transcription factors (OCT4 and SOX2). (b) CBiPS colonies grow as compact and domed colonies that express alkaline phosphatase (AP). Scale bar, $100 \mu \mathrm{m}$.

aspirate the medium gently using a 1-ml pipette and to add fresh medium dropwise to prevent the few cells attached to the feeder from coming off (Fig. 4b).

63| After $9 \mathrm{~d}$ small colonies start to appear. At $15 \mathrm{~d}$ of culture the colonies exhibit typical hESC morphology (Fig. 5a,b).

Picking and expanding iPS cell colonies $\bigcirc$ TIMING $\sim 9 \mathrm{~d}$ 64| Day 1: identify colonies of iPS-like morphology and mark them on the bottom of the dish under the inverted microscope.

65| Prepare the required number of 6-well plates with irradiated HFF feeder layers, calculating 1-well per colony to be picked.

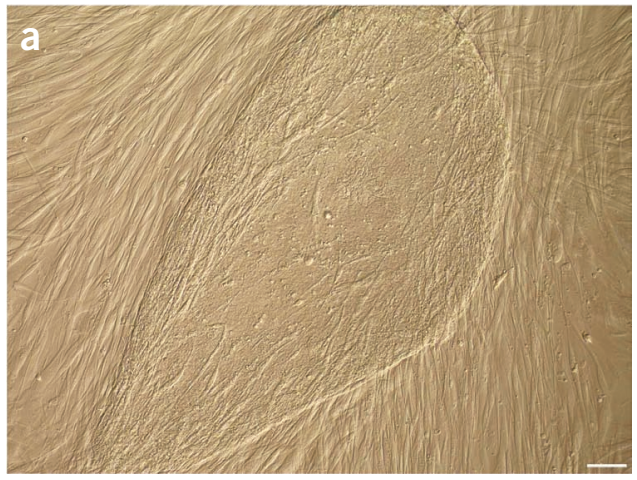

66| Day 2: aspirate the medium and add $2 \mathrm{ml}$ of fresh hES medium in each well of the reprogramming dishes and 6 -well feeder plates.

67| Place the plate in a $37^{\circ} \mathrm{C}, 5 \% \mathrm{CO}_{2}$ incubator for $20 \mathrm{~min}$.

68 Working on the stereomicroscope placed inside a tissue culture hood, manually pick the single colonies from each well using a stripper micropipette. Transfer colony fragments into a well with an HFF feeder. Incubate in a $37{ }^{\circ} \mathrm{C}, 5 \% \mathrm{CO}_{2}$ incubator.

$\triangle$ CRITICAL STEP To avoid cross-contamination with colonies originated in the same well, pick each colony with a new micropipette.

69| Day 4: change the medium in each well. Many colony fragments should be attached to the feeder.

70| Days 5-9: change the medium daily. Attached colony fragments will form iPS-like colonies, ready to be passaged by days $8-9$.

\section{Freezing of iPS cells $\bigcirc$ TIMING $\sim 1 \mathrm{~h}$}

71| Aspirate the medium and add $2 \mathrm{~mL}$ of fresh hES medium in each well.

72| Pick approximately 20 colonies from each well and transfer the cell suspension in a 15-ml tube containing $2 \mathrm{ml}$ pre-warmed hES medium. Centrifuge for $1 \mathrm{~min}$ at $200 \mathrm{~g}$ at room temperature and aspirate the supernatant.

73| Drop-by-drop, add $1 \mathrm{ml}$ of freezing medium and transfer the cells into freezing vial.

74| Keep the vials in a cell-freezing container overnight at $-80^{\circ} \mathrm{C}$ and then transfer them into a liquid nitrogen tank the next day.

! CAUTION Liquid nitrogen is dangerous; use special protective clothing.

\section{TIMING}

Step 1, Umbilical CB collection: $\sim 5$ min

Steps 2-10, Isolation of umbilical CB mononuclear cells using Lympholyte- $\mathrm{H}$ density gradient: $\sim 2 \mathrm{~h}$

Steps 11-27, Isolation of CD133 + cells: $\sim 1 \mathrm{~h}$ 
Steps 28-41, Retrovirus production: 1 week

Steps 42-57, Retroviral transduction of CD133 + cells: $\sim 2 \mathrm{~d}$

Steps 58-63, Culturing transduced CD133 + cells: $\sim 2$ weeks

Steps $64-70$, Picking and expanding iPS cell colonies: $\sim 9 \mathrm{~d}$

Steps 71-74, Freezing of iPSC: $\sim 1 \mathrm{~h}$

\section{? TROUBLESHOOTING}

Troubleshooting advice can be found in Table 1 .

TABLE 1 | Troubleshooting table.

\begin{tabular}{llll}
\hline Step & Problem & Possible reason & Solution \\
\hline 9 & $\begin{array}{l}\text { White fiber formation } \\
\text { during the process }\end{array}$ & $\begin{array}{l}\text { Contamination of cells } \\
\text { suspension with } \\
\text { platelets }\end{array}$ & $\begin{array}{l}\text { Centrifuge cells slowly } 200 \times \mathrm{g} / 5 \text { min; discard the supernatant with } \\
\text { platelets }\end{array}$ \\
$\begin{array}{lll}\text { Viral titer is low } \\
\text { Low infection efficiency }\end{array}$ & $\begin{array}{l}\text { Ensure that Phoenix Amphotropic cells are healthy and the transfection } \\
\text { efficiency is close to } 100 \% \text {. Use low passage Phoenix cells }\end{array}$ \\
& $\begin{array}{l}\text { Infectivity of other } \\
\text { cell lines is high }\end{array}$ & $\begin{array}{l}\text { Ensure to work with a purity of CD133+ cells more thank } 90 \% . \text { Extend } \\
\text { the centrifugation to promote viral vectors binding to Retronectin } \\
\text { to } 2 \mathrm{~h}\end{array}$ \\
\hline
\end{tabular}

\section{ANTICIPATED RESULTS}

Cord blood CD133 + cells represent a small fraction of total nucleated cells $(0.1-0.5 \%)$ in one CB unit. Depending on the quality of the CB unit (total volume of CB, total number of nucleated cells, the percentage of CD133 + cells and the age of the $\mathrm{CB}$ unit), the recovery and the purity of $\mathrm{CD} 133+$ cells after immunoselection can vary (from 400,000 to $1.2 \times 10^{6}$ CD133 + cells, with a purity range of $90-94 \%)$ (Fig. 6 a).

On average, $8 \times 10^{4} \mathrm{CD} 133+$ cells seeded over retronectin-coated plates previously pre-absorbed with viral particles (Fig. 4) and infected with OS give rise to five iPS colonies in 12-15 d. CBiPS colonies exhibited typical hESC morphology with sharp borders and small, tightly packed cell population with large nuclei (Fig. 5). CBiPS cells show a differential potential similar to hESC in vitro, and when injected into immunocompromised SCID mice, CBiPS cells generate complex intratesticular teratomas, comprising structures and tissue derived from the three embryonic germ layers (Fig. $\mathbf{6 b}, \mathbf{c}$ ). In addition, CBiPS cells show a genome-wide transcriptional profile similar to hESC and other iPS cell lines (Fig. $6 \mathbf{d})^{12}$.

Figure 6 | Characterization of CD133 + and cord blood-induced pluripotent stem (CBiPS) cells. (a) Representative dot-plot for CD133 cells after standard immunoselction. (b) Hematoxylin and eosin staining of teratomas derived from SCID Beige mice injected with CBiPS2F cells show tissues representative of all three embryonic germ layers, including cartilage and smooth muscle (mesoderm), gut epithelium (endoderm) and immature neural tissue (ectoderm). (c) Fluorescent microscope staining of teratoma sections reveal the presence of derivates of the three embryonic germ layers (Tuj1 (green)/GFAP (red)-positive ectoderm, AFP (green)/FoxA2 (red)-positive endoderm and ASM (green)/ASA (red)-positive mesoderm. Scale bar, 25-50 $\mu \mathrm{m}$. Experiments using laboratory animals complied with the institutional and national guidelines. (d) Principal component analysis shows that CBiPS2F have a similar gene expression profile to human ES cell (hES) and other iPS cell lines derived in our laboratory.
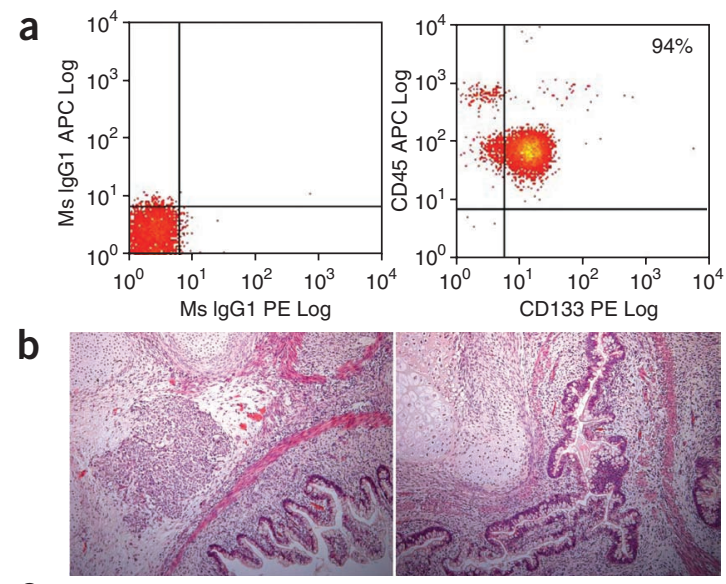

C

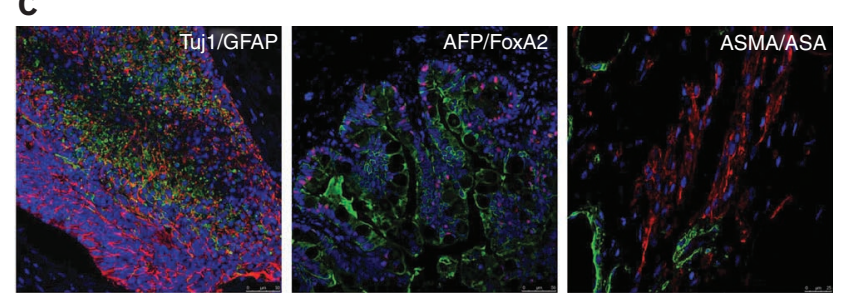

d

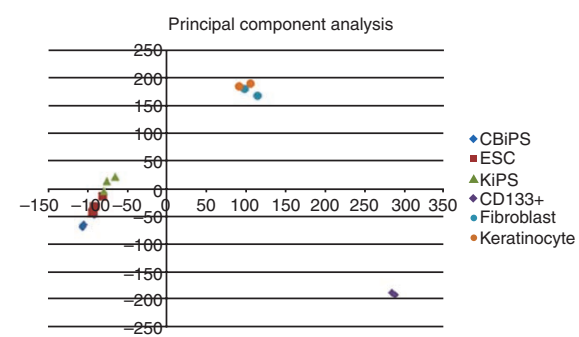


PROTOCOL

ACKNOWLEDGMENTS We thank Dr. M. Torrabadella, Director of the Banc de Sang i Teixits, Vall d'Hebron for providing cord blood units. We are grateful to Y. Muñoz Santos for expert assistance with cell culture techniques. N.M. was partially supported by the Juan de la Cierva program. This work was partially supported by grants from MICINN, CIBER, the Fondo de Investigaciones Sanitarias (RETIC-RD06/0010/0016), TERCEL, the G. Harold and Leila Y. Mathers Charitable Foundation and Fundación Cellex.

AUTHOR CONTRIBUTIONS A.G.: protocol design, isolation of CB CD133 + cells, generation of iPS cell lines and preparation of manuscript; N.M.: protocol design, isolation of CB CD133 + cells, generation of iPS cell lines and preparation of manuscript; I.R.-P.: characterization of iPS cell lines; C.A.: characterization, selection and provision of CB units; A.V.: preparation of manuscript; and J.C.I.B.: preparation of manuscript.

Published online at http://www.natureprotocols.com/.

Reprints and permissions information is available online at http://npg.nature.com/ reprintsandpermissions/.

1. Takahashi, K. et al. Induction of pluripotent stem cells from adult human fibroblasts by defined factors. Cell 131, 861-872 (2007).

2. Aasen, T. et al. Efficient and rapid generation of induced pluripotent stem cells from human keratinocytes. Nat. Biotechnol. 26, 1276-1284 (2008)
3. Kim, J.B. et al. Direct reprogramming of human neural stem cells by OCT4. Nature 461, 649-643 (2009).

4. Loh, Y.H. et al. Generation of induced pluripotent stem cells from human blood. Blood 113, 5476-5479 (2009).

5. Ye, Z. et al. Human induced pluripotent stem cells from blood cells of healthy donors and patients with acquired blood disorders. Blood 24, 5473-5480 (2009).

6. Haase, A. et al. Generation of induced pluripotent stem cells from human cord blood. Cell Stem Cell 5, 434-441 (2009).

7. Eminli, S., Utikal, J., Arnold, K., Jaenisch, R. \& Hochedlinger, K. Reprogramming of neural progenitor cells into induced pluripotent stem cells in the absence of exogenous Sox2 expression. Stem Cells 26, 2467-2474 (2008).

8. Kim, J.B. et al. Pluripotent stem cells induced from adult neural stem cells by reprogramming with two factors. Nature 454, 646-650 (2008).

9. Anderlini, P. Effects and safety of granulocyte colony-stimulating factor in healthy volunteers. Curr. Opin. Hematol. 16, 35-40 (2009).

10. Gluckman, E. History of cord blood transplantation. Bone Marrow Transplant. 44, 621-626 (2009).

11. Gluckman, E. \& Rocha, V. Cord blood transplantation: state of the art. Haematologica 94, 451-454 (2009).

12. Giorgetti, A. et al. Generation of induced pluripotent stem cells from human cord blood using OCT4 and SOX2. Cell Stem Cell 5, 353-357 (2009). 